УДК 373.5.091:821.161.2:004.42

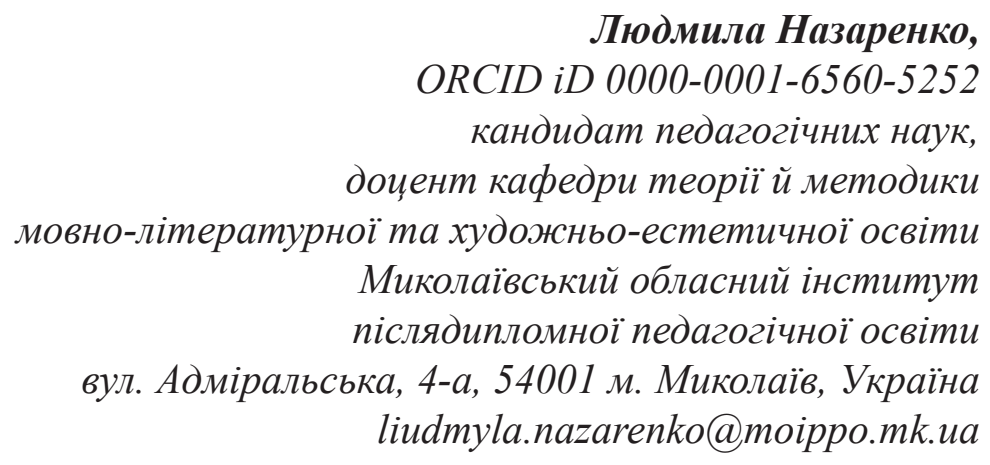

\title{
ЕФЕКТИВНІСТЬ ФОРМУВАННЯ ЛІТЕРАТУРНОЇ КОМПЕТЕНТНОСТІ СТАРШОКЛАСНИКІВ ЗАСОБАМИ ІКТ (СТАРША ШКОЛА)
}

У статті актуалізовано потребу якісних перетворень в освіті, зміни поглядів на систему викладання літератури у зв'язку з новою стратегією підготовки випускників закладів загальної середньої освіти. 3 'ясовано суперечності між використанням учителями традиційних форм і методів навчання і потребою в інноваціях; ретранслюванням отриманих знань і самостійним здобуттям інформації з предмета, ї̈ перетворенням та репрезентацією; поодиноким використанням елементів проєктного навчання, синергетичного підходу й необхідністю в забезпеченні компетентнісно-діяльнісної парадигми учасниками освітнього прочесу. Поглиблено зміст і сутність поняття «літературна компетентність» (ЛК) учнів-читачів. Запропоновано функиії, критерії, ключові компоненти сформованості ЛК старшокласників. Розроблено методичну модель формування літературної компетентності учнів із використанням засобів ІКТ. Висвітлено можливості формування ЛК у проиесі технологізованого навчання на уроках літератури, діалогічної взаємодії між автором, твором і читачем.

Ключові слова: аналіз художнього твору; експеримент; інформачійно-комунікаціиині технологї (IКТ); літературна компетентність (ЛК); практичні завдання; проєктна діяльність; усвідомлене сприймання.

(C) Назаренко Л. А., 2021

Вступні зауваги. В умовах розвитку літературної освіти важливого значення набуває підвищення рівня іï якості та ефективності, формування когнітивних i творчих здібностей учнів, їхніх компетентностей. Такі перетворення вимагають оновлення в освітній практиці, яка орієнтована на підготовку компетентних випускників закладів загальної середньої освіти. У Законі «Про освіту» (2017 р.) зазначено, що метою навчання $\epsilon$ всебічний розвиток людини як особистості, iї талантів, інтелектуальних, творчих здібностей, формування цінностей i необхідних для успішної самореалізації компетентностей, підвищення освітнього рівня громадян задля забезпечення сталого розвитку України та її європейського вибору. Це свідчить про необхідність змін у ставленні до викладання, мотивуванні майбутніх випускників до набуття умінь здійснювати самостійну пізнавальну роботу.

Проблеми сутності інновацій досліджували І. П. Підласий, В. Ф. Паламарчук, О. Я. Савченко. Значну увагу розробленню різноманітних новітніх моделей змісту педагогічної освіти приділяли І. А. Зязюн, М. Б. Євтух, О. А. Ду- 
басеню. Дидактичні аспекти проєктного навчання з використанням засобів ІКТ висвітлювали в працях як зарубіжні (О. Едвардс, Г. В. Лаврентьєв, Н.Б. Лаврентьєва, І. Я. Лернер, С. Пейперт, І. Сєргєєв, О. Н. Шилова), так і українські вчені (Р. С. Гуревич, Ю. О. Жук, М. Ю. Кадемія, О. М. Пєхота, Є. С. Полат). Використання засобів ІКТ у процесі літературної освіти спостерігаємо в дослідженнях О. С. Авраменка (використання відео- й аудіохостингів); Т. В. Бабійчук (вивчення художніх творів із використанням відеофрагментів); Г. Л. Бійчук (застосування мультимедіа в навчанні літератури); В. В. Оліфіренка (комп’ютерні технології на уроках літератури), В. В. Різуна (медійні технології на уроках літератури); В. В. Уліщенко особливості медіанавчання в ході інтерсуб'єктного вивчення літератури). Методисти з'ясували основоположні методи, прийоми, форми організації навчальної діяльності на основі технології Веб 2.0. (друге покоління). Донині лишається системно не розробленим питання ефективності формування літературної компетентності через використання засобів IКТ, інтернет-технологій третього покоління, зокрема хмарних, використання геосервісів, Smart-технологій, Web Syndication.

\section{Постановка проблеми.}

Актуальність проблеми зумовлена суперечностями між використанням учителями традиційних форм і методів навчання та потребою в інноваціях; ретранслюванням отриманих знань і самостійним здобуттям інформації з предмета, іiі перетворенням та репрезентацією; поодиноким використанням елементів проєктного навчання, синергетичного підходу й необхідністю в забезпеченні компетентнісно-діяльнісної парадигми учасниками освітнього процесу.

Мета статті - показати ефективність формування в учнів 10-11-х класів літературної компетентності за допомогою нових засобів ІКТ. Завдання:

1. Проаналізувати погляди учених на літературну компетентність.

2. Розробити й теоретично обгрунту- вати методичну модель формування літературної компетентності (ЛК) старшокласників засобами IКT.

3. Дослідити ефективність розробленої методики й подати результати експериментального навчання.

Матеріали і методи: у роботі використаний комплекс методів: загальнонаукових (аналіз, синтез, порівняння, зіставлення, систематизація, узагальнення), емпіричних (спостереження, бесіди, анкетування).

\section{Аналіз досліджень і публікацій.}

Підгрунтям дослідження навчальної діяльності з використання засобів ІКТ $\epsilon$ праці таких вітчизняних науковців, як: В. В. Биков, Р. С. Гуревич, Ю. О. Жук, М. Ю. Кадемія, С. С. Полат, І. В. Родигіна, зарубіжних: Р. Естріягана, К. Зубарев, М. Н. Лебедєва, Х. -О. Медіна-Меродіо, Р. Плата, Р. Уайт, М. Уїммер; у галузі вивчення гуманітарних предметів: Т. В. Бабійчук, О. В. Бігич, Г. Л. Бійчук, О. О. Ісаєва, С. Васюта, Л. А. Найдьонова, В. В. Оліфіренко, О. М. Семеног, В. В. Уліщенко.

Засадничими ідеями для дослідження, що забезпечують передумови для розуміння готовності учнів до літературної діяльності, використання ними засобів ІКТ, є такі: урахування міжпредметних зв'язків, індивідуалізації та гуманізації навчання, (Ушинський К. Д., 1983), самостійного перенесення знань і вмінь у нову ситуацію (Лернер I. Я., 1971), урахування принципів особистісно зорієнтованого навчання (Якиманская И. Я., 1996), зорієнтованість на продуктивність навчання (Хуторской А. В., 2001), формування компетентності як здатності до найефективнішого застосування знань (Бібік Н. М., 2008, Селевко Г. К., 2005), поетапне формування розумових умінь (Ситченко А. Л., 2004), використання на уроках технологізованої діяльності (Пехота О. М., 2001).

Для нашого дослідження важливим $\epsilon$ формування інформаційно-комунікаційної, проєктно-технологічної, літературної компетентностей. Остання, на переконання В. I. Шуляра (Шуляр В. I., 2009, с. 24), пе- 
редбачає володіння такими компетенціями: читацькою, літературознавчою, металінгвістичною, комунікативно-мовленнєвою, когнітивною, прогностичною, соціальною, технологічною, аксіологічною, інформаційною, візуалізаційною, фасилітативною, креативною, рефлективною, валеологічною, організаційною. Одним із ключових механізмів формування ЛК випускника-читача, на думку вченого (Шуляр В. I., 2015, с. 16), є етап поєднання філологічних знань 3 їхнім досвідом у ситуації суб'єктної позиції під час освітньо-мистецької діяльності культурологічного спрямування. Ефективне навчання можливе, якщо організувати літературну діяльність учнів, за якої враховувалася би специфіка предмета. Маємо на увазі читацьку діяльність учнів і розв'язання проблем, що виникають у процесі формування навичок спілкування $з$ виучуваним твором, неоднозначністю його сприйняття учнями, сприянні набуттю балансу між емоційною перцепцією та інтелектуальною інтерпретацією художнього твору (Назаренко Л. А., 2017, с. 31).

$€$ ймовірність уподібнення та взаємозаміни понять «літературна компетентність» / «читацька компетентність», тому вагомою для дослідження є думка А. М. Фасолі (Фасоля А. М., 2012, с. 28), який переконаний, що маємо говорити про читацьку міжпредметну (ключову) й читацьку предметну (iіi можна назвати літературною) компетентності. У першому випадку читацька компетентність є складовою інформаційно-комунікаційної, формуватиметься на міжпредметному рівні, у другому - іiі становлення відбуватиметься засобами літератури, тому поняття не тотожні. Опорою для дослідження є поняття «літературна компетентність».

Терміни «читацька компетентність» / «літературна компетентність» розрізняе T. О. Яценко (Яценко Т. О., 2012, с. 9). На думку вченої, поняття «читацька компетентність» означає здатність до творчого читання всього твору, а не його фрагментів; сформованість власного кола читання; здатність вступати в діалог з епохою й куль- турою, втіленими в художніх творах, здатність до співпереживання 3 персонажами літературних творів; розуміння специфіки мови художнього твору, вміння розрізняти стилі художніх текстів. ЛК Т. О. Яценко (Яценко Т. О., 2012, с. 38) розуміє як умовне поєднання особистісного, когнітивного та діяльнісного компонентів, взаємодія яких у читацькій діяльності й забезпечує (або не забезпечує) розвиток ЛК. Це означає, що компетентні читачі мають володіти літературними засобами пізнання художнього твору, переконливо доводити власні міркування, реалізувати творчі здібності, мати стійкий інтерес до читання. Таким чином активізовано основні компетенції: читацьку, когнітивну, креативну, комунікативно-мовленнєву.

Про формування ЛК свідчить розвиток людини, iii особистісні й соціальні зміни, здатність до ціннісних орієнтирів. Розглядаючи компетентність як психічне утворення, Г. Л. Токмань (Токмань Г. Л., 2003 , с. 28) виокремлює в компоненти: емоційно-ціннісний (почуття, настанови, мотиви, якості, емоції, пов'язані $з$ позитивним досвідом та ін.); когнітивний (знання предметні, а також про себе, діяльність тощо); практичний (предметні й загальнонавчальні вміння, позитивний досвід діяльності), що вказує на цілісність емоційного, знаннєвого й прикладного складників. У такий спосіб акцентується увага на літературознавчій, комунікативно-мовленнєвій, когнітивній, прогностичній і соціальній компетенціях.

Опорою дослідження 3 формування літературної компетентності, аналітичних здібностей і духовних рис учнів-читачів $\epsilon$ розвідка А. Л. Ситченка (Ситченко А. Л., 2004 , с. 138), який указує на важливість урахування навчального і чуттєвого досвіду, знань і вмінь школярів, а також психічних новоутворень, які знаменують розвиток. Долаючи в процесі художнього сприймання відстань між структурними елементами тексту та їхньою ідейно-образною функці$є ю$, читачі не лише наближаються до повноти вражень від твору, а й виробляють 
уміння розв'язувати літературні задачі різного типу. У цьому аспекті активізуються читацька, когнітивна, прогностична, аксіологічна, організаційна компетенції.

На важливість читацького розвитку вказує I. О. Небеленчук (Небеленчук I. О., 2011, с. 29), яка виокремлює такі складники ЛК: когнітивну, мотиваційну, аксіологічну, рецептивну, комунікативну, естетичну, проєктувальну, коригувальну, та О. Н. Шкловська (Шкловська О. Н., 2007, c. 9), яка представляє читацьку компетенцію за наявності таких умовних компонентів: особистісного, когнітивного й діяльнісного. На основі праць I. О. Небеленчук, А. Л. Ситченка, Г. Л. Токмань, О. Н. Шкловської пропонуємо ключовими компонентами ЛК уважати такі: мотиваційний, емоційно-ціннісний, когнітивно-діяльнісний, комунікативний, соціокультурний, позаяк вони найповніше віддзеркалюють зміст цього поняття. Отже, ЛК - це інтеграційне утворення, що забезпечує цілісне сприймання художнього тексту, розширює читацькі інтереси на діяльнісній основі, орієнтоване на особистісний розвиток учнів, їхню успішність, активне застосування вмінь, утворення ціннісних надбань.

Сучасний розвиток освіти потребує інноваційних підходів у освіті. На цьому наголошував С. Фріман (Фріман С., 2009, с. 585). Використання сучасних засобів навчання, з погляду вченого, здатне не лише зацікавити предметом, а й переймати на себе керівну роль у засвоєнні й опрацюванні інформації. Суголосною є думка й Квок Він Лай (Квок Він Лай, 2015, с. 12), який указує на проблему одноманітності використання спектра цифрових технологій. Усе зазначене вище свідчить про потребу формування ЛК, цілісного світобачення школярів завдяки використанню ресурсів Інтернету, засобів IКТ, інтеграційним зв'язкам між предметами, кооперації й колаборації.

Освіта, як зазначає Р. Естріягана (Естріягана Р., 2019), заснована на компетентностях, є центральною опорою для вищої освіти, рівень якої можна підвищити за допомогою різних підходів, по-перше, даючи відповіді на запитання про те, які компетенції або навички потрібні, або які 3 них можна розробити під час навчання? По-друге, як виміряти їх? По-третє, які методи та інструменти викладання / навчання $\epsilon$ більш прийнятними для досягнення цих ключових компетенцій? Ці компетенції, на думку Султан (2018), охоплюють концептуальні знання, навички критичного та творчого мислення, а також спілкування i співпраці.

Завданням дослідження формувального етапу експерименту стали розроблення й теоретичне обгрунтування методичної моделі формування ЛК старшокласників засобами IКТ (Рис. 1).

Ïї використання спрямовано на реалізацію таких функцій: діагностичної; мотиваційної, емоційно-ціннісної, когнітивної, діяльнісної, комунікативної, соціокультурної. У зв'язку з тим, що організація експериментальної роботи потребує опори на диференційований і творчий підхід у навчанні, урахування індивідуальних особливостей сприймання художнього твору, рівня сформованості ЛК учнів, психолого-педагогічних умов, пропонуємо критерії сформованості ЛК старшокласників:

1) сформованість пізнавального інтересу старшокласників;

2) оволодіння вміннями й навичками аналізу художнього твору;

3) усвідомлення учнями способів виконання навчальних завдань із використанням засобів IКТ;

4) здійснення самостійної естетичної оцінки художнього твору.

Сформовану ЛК старшокласників засобами ІКТ та Інтернету на основі праць I. О. Небеленчук, Г. Л. Токмань, О. Н. Шкловської представлено в розвідці за допомогою таких компонентів: мотиваційного, когнітивно-діяльнісного, емоційно-ціннісного, комунікативного, соціокультурного, які тісно пов'язані з індикаторами, що сигналізують про сформованість ЛК 
засобами ІКТ, оскільки вказують на різ- ють компетентнісний підхід до навчання новекторність читацької діяльності учнів, предмета.

їхню літературну досвідченість, урахову-

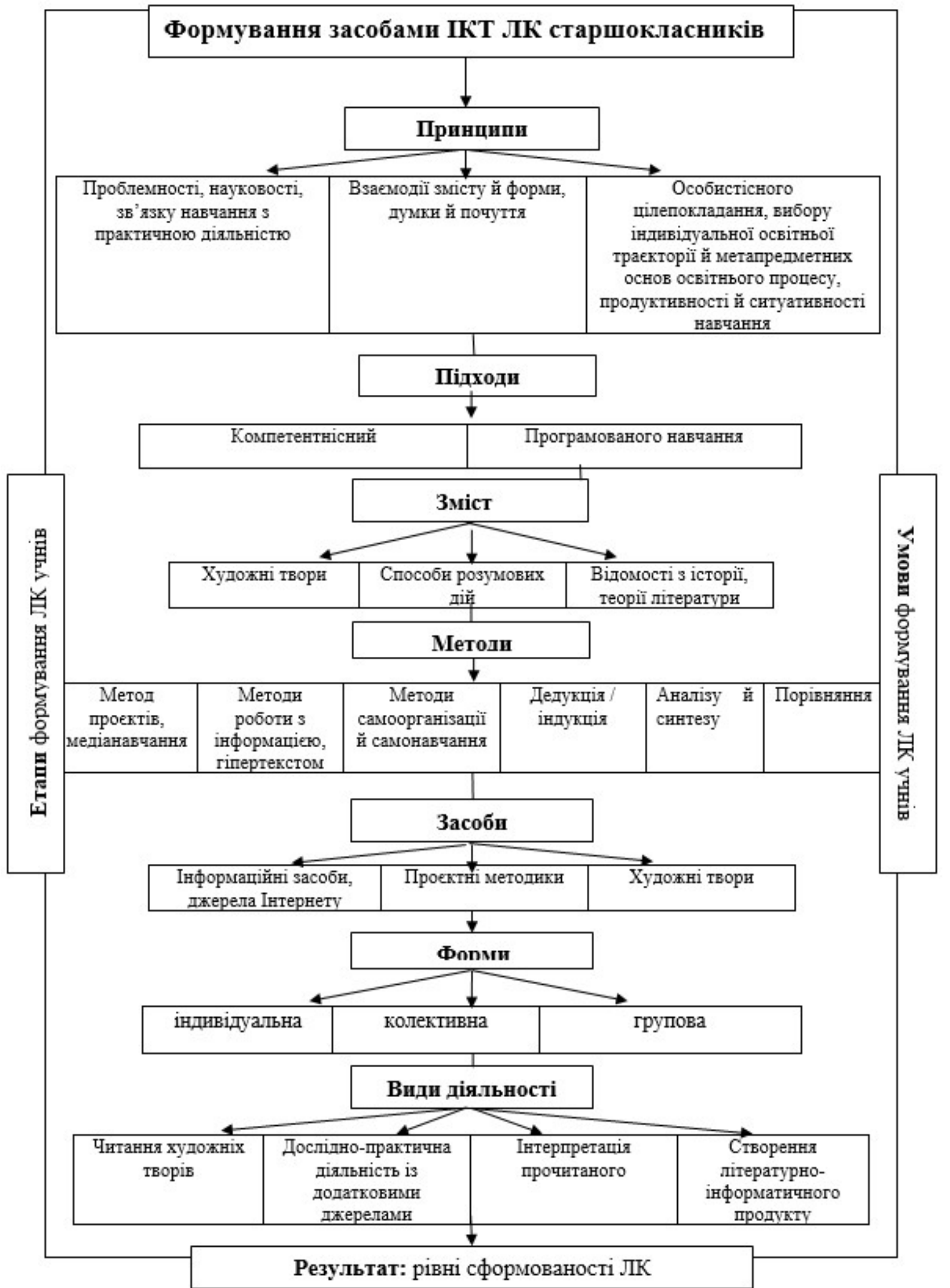

Рис. 1. Методична модель формування ЛК учня-читача засобами IКТ

Джерело складено автором самостійно 
Мотиваційний компонент містить такі показники:

1) уміння учнем здійснювати ціннісну мотивацію до літературної діяльності, виявляти здатність до систематичного читання;

2) уміння визначати власні читацькі потреби, виявляти інтерес до літературного процесу, жанрів літератури;

3) уміння старшокласником адекватно реагувати на поради, настанови словесника, однокласників.

Когнітивно-діяльнісний має такі складники:

1) уміння самостійно й усвідомлено визначати мету й завдання власної читацької діяльності, акумулювати досвід роботи 3 художнім твором із метою задоволення особистих читацьких потреб, виявлення загальної ерудиції, естетичного розвитку;

2) здатність реципієнта до аналітико-синтетичної діяльності, критичного мислення, розуміння задуму й осмислення своєрідності стилю автора, формотворчих характеристик тексту;

3) уміння орієнтуватись у світі літератури, відтворювати, аналізувати й інтерпретувати художній твір, використовувати літературознавчі терміни, брати участь у пошуково-дослідницькій, творчій, проєктній діяльності, установлювати інтертекстуальні зв'язки 3 мистецькими явищами, здійснювати компаративний аналіз творів.

Емоційно-ціннісний компонент охоплює такі прояви:

1) здатність читача до інтелектуально-чуттєвого сприймання i його відображення у творчих проєктах, висловлення ставлення до прочитаного;

2) надання оцінки вартісності художнього твору, здатність до емпатії, поділу враженнями й почуттями, творчого читання;

3) формування естетичного смаку, виявлення захоплення красою слова.

Комунікативний містить такі показники:

1) творення усного / письмового монологічного висловлювання, моделювання комунікативної ситуації учнем-читачем;

2) здатність до співробітництва, де поєднується комунікативна діяльність із читацьким досвідом старшокласників; використання мовних засобів, з'ясовування значення незрозумілих слів;

3) стала активність у навчанні літератури.

Соціокультурний передбачає такі складники:

1) формування гуманістичного світогляду, вивчення художнього твору як явища мистецтва; формування світоглядних i загальнолюдських ціннісних орієнтирів;

2) розуміння сутності літературно-мистецької інформації, уміння iii перетворювати; відчувати відповідальність за вірогідність інформації, отриманої з додаткових джерел;

3) сприяння розвитку духовної культури, усвідомлення національного й загальносвітового значення художнього твору.

Наведені компоненти та показники сформованості ЛК служать вихідними даними для визначення рівнів розвитку цієї якості засобами IКТ в учнів 10-11-х класів закладів загальної середньої освіти - початковий, основний (середній), функціональний (достатній), творчий (високий). Розподіл за такими рівнями здійснюється відповідно до програмових вимог, критеріїв оцінювання сформованості ЛК старшокласників.

Валідація навчальних матеріалів.

Проведення формувального етапу експерименту дало змогу констатувати той 
факт, що реалізація розробленої моделі в процесі навчання сприяла організації проєктної діяльності читачів із метою набуття ними літературної компетентності. Формувальний етап експерименту засвідчив, що дослідницька, пошукова, творча діяльність уможливили реалізацію потенціалу старшокласників, що сприяло розвиткові інтересу до літератури, оригінальному виконанню творчих завдань. У процесі експерименту враховано рівень здібностей учнів, їхньої ЛК, що визначало ступінь допомоги з боку вчителя, учнів-консультантів.

Аналіз виконання літературних за- вдань школярами в контрольних класах (КК) та експериментальних класах (ЕК), відповіді на повторне анкетування дали змогу провести порівняльний аналіз отриманих результатів, узагальнити їх і відтворити кількісні показники в таблицях 1.1, 1.2. Для обчислення компетенцій у пригоді стали анкети, розроблені Е. Брауном (Браун Е., 2009) і Б. Лейднером (Лейднер Б., 2012) із погляду участі в проєктуванні, де маркерами є систематичні, особисті, кооперативні, презентаційні та комунікаційні компетенції, оскільки навчання здійснюється як очно, так і дистанційно.

Порівняльні показники рівнів сформованості ЛК учнів засобами IКT

\begin{tabular}{|c|c|c|c|c|c|c|c|c|}
\hline \multirow{2}{*}{ Ківні } & \multicolumn{5}{|c|}{ ЕК (310 учнів) } & \multicolumn{3}{c|}{ КК (334 учні) } \\
\cline { 2 - 9 } & Початк. & Основн. & Функціон. & Творч. & Початк. & Основн. & Функціон. & Творч. \\
\hline мотиваційний & 8 & 45 & 172 & 85 & 28 & 110 & 161 & 35 \\
& $(2,6 \%)$ & $(14,5 \%)$ & $(55,5 \%)$ & $(27,4 \%)$ & $(8,4 \%)$ & $(32,9 \%)$ & $(48,2 \%)$ & $(10,5 \%)$ \\
\hline когнітивно- & 9 & 46 & 141 & 114 & 21 & 105 & 165 & 43 \\
діяльнісний & $(2,9 \%)$ & $(14,8 \%)$ & $(45,5 \%)$ & $(35,8 \%)$ & $(6,3 \%)$ & $(31,5 \%)$ & $(49,4 \%)$ & $(12,8 \%)$ \\
\hline емоційно- & 12 & 41 & 142 & 115 & 19 & 103 & 167 & 45 \\
ціннісний & $(3,9 \%)$ & $(13,2 \%)$ & $(45,8 \%)$ & $(37,1 \%)$ & $(5,6 \%)$ & $(30,3 \%)$ & $(50,6 \%)$ & $(13,5 \%)$ \\
\hline комунікативний & 11 & 43 & 160 & 96 & 31 & 107 & 156 & 40 \\
& $(3,5 \%)$ & $(13,9 \%)$ & $(51,6 \%)$ & $(31 \%)$ & $(9,2 \%)$ & $(41,3 \%)$ & $(46,8 \%)$ & $(11,9 \%)$ \\
\hline соціокультурний & 10 & 42 & 156 & 102 & 32 & 117 & 152 & 33 \\
& $(3,2 \%)$ & $(13,5 \%)$ & $(50,4 \%)$ & $(32,9 \%)$ & $(9,6 \%)$ & $(35 \%)$ & $(45,5 \%)$ & $(9,9 \%)$ \\
\hline
\end{tabular}

Джерело складено автором самостійно

Таблиця 1.2

Порівняльні показники рівнів сформованості ЛК старшокласників засобами IКТ

\begin{tabular}{|c|c|c|c|c|c|c|c|c|}
\hline \multirow{3}{*}{ 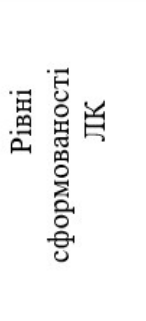 } & \multicolumn{4}{|c|}{ Діяльнісний етап } & \multicolumn{4}{|c|}{ Продуктивний етап } \\
\hline & \multicolumn{2}{|c|}{ КК } & \multicolumn{2}{|c|}{ EK } & \multicolumn{2}{|c|}{ КК } & \multicolumn{2}{|c|}{ EK } \\
\hline & 总惫 & $\%$ & 总息 & $\%$ & 总畠 & $\%$ & 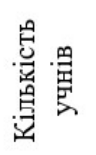 & $\%$ \\
\hline Початк. & 44 & 13,2 & 35 & 11,3 & 26 & 7,8 & 16 & 5,2 \\
\hline Основн. & 146 & 43,7 & 145 & 46,8 & 114 & 34,2 & 38 & 12,2 \\
\hline Функц. & 122 & 36,5 & 92 & 29,7 & 161 & 48,1 & 154 & 49,8 \\
\hline Творч. & 22 & 6,6 & 38 & 12,2 & 33 & 9,9 & 102 & 32,8 \\
\hline
\end{tabular}

Джерело складено автором самостійно 
Учні експериментальних і контрольних груп (КГ, ЕГ) із задоволенням брали участь у пошуковій, дослідницькій і творчій роботі, що позначилося на мотивації до навчання й зростанні їхніх кваліфікаційних навичок. Дані, наведені в таблиці, дають змогу дійти таких висновків: 1) у групі учнів творчого рівня з високою сформованістю ЛК засобами ІКТ у ЕК спосте- рігається покращення результатів: зростання - 20,6\% (32,8 \% проти 12,2 \%); 2) ЛК старшокласників функціонального рівня в ЕК становить 49,8 \%, що вказує на покращення результату (20,1 \%). Порівняно 3 початком експерименту показник учнів із низьким і основним рівнями сформованості ЛК зменшився, розбіжність становить $6,1 \%$ i $34,6 \%$.

Діаграма 1.0

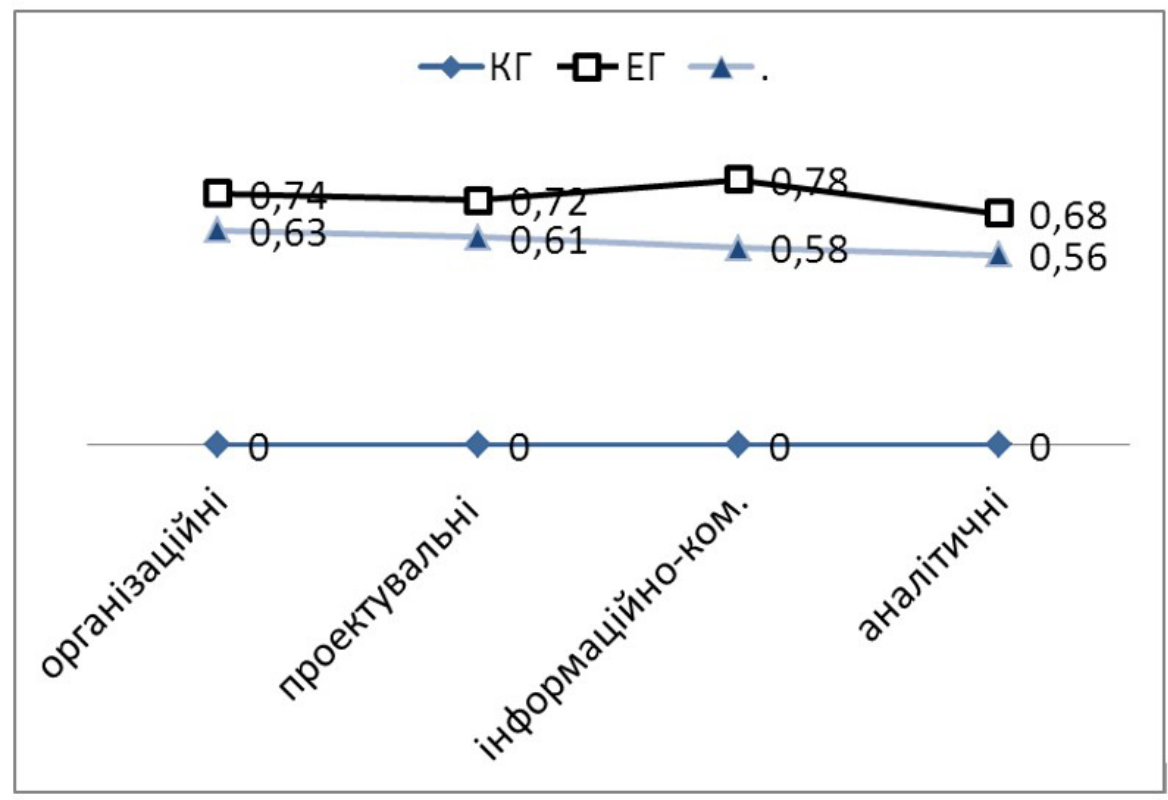

Джерело складено автором самостійно

Крім того, відповідаючи на запитання анкети, старшокласники засвідчили необхідність використання засобів ІКТ не лише в урочний, а й у позаурочний час для розуміння змісту художніх творів, набуття літературних компетенцій. Результати опитування подано в таблиці.

Таблиця 1.3

\begin{tabular}{|c|c|c|c|c|c|}
\hline \multirow[t]{2}{*}{ № } & \multirow[t]{2}{*}{ Запитання } & \multicolumn{2}{|c|}{ Так } & \multicolumn{2}{|c|}{$\mathrm{Hi}$} \\
\hline & & К-ть & $\%$ & К-ть & $\%$ \\
\hline 1. & Чи сприяють засоби ІКТ розумінню художніх творів? & 293 & 94,5 & 17 & 5,5 \\
\hline 2. & $\begin{array}{l}\text { Чи дають змогу розроблені й запропоновані завдання } \\
\text { оволодіти літературними компетенціями? }\end{array}$ & 280 & 90,3 & 30 & 9,7 \\
\hline 3. & $\begin{array}{l}\text { Чи доцільне використання засобів IКТ у системі } \\
\text { літературної освіти в старшій школі? }\end{array}$ & 285 & 92 & 25 & 8 \\
\hline 4. & $\begin{array}{l}\text { Чи хотіли б ви використовувати засоби IКТ на } \\
\text { позакласних заняттях з предмета? }\end{array}$ & 287 & 92,6 & 7 & 7,4 \\
\hline 5. & $\begin{array}{l}\text { Чи ви } є \text { прихильником уроків літератури дистанційної } \\
\text { форми співпраці «учні-читачі - художній твір - } \\
\text { учитель літератури»? }\end{array}$ & 280 & 90,3 & 6 & 9,7 \\
\hline 6. & $\begin{array}{l}\text { Чи доречним } є \text { використання тестових програм для } \\
\text { перевірки знань із літератури? }\end{array}$ & 299 & 96,5 & 10 & 3,5 \\
\hline
\end{tabular}

Джерело складено автором самостійно 


\section{Ефективність навчальних ма- теріалів.}

Валідація продукту (навчальних матеріалів, моделі) доведена вчителями й учнями, які брали участь у експерименті. Отримані результати вказують на значне зростання літературної компетентності старшокласників унаслідок використання засобів ІКТ, підвищення рівня їхньої мотивації до навчання. Схвальні відгуки школярів про навчання на новому для них рівні вказують на ефективність запропонованої методики й розроблених матеріалів, об'єктивність оцінювання потенційних можливостей учнів. Практико-орієнтовані завдання поєднують у собі знання з різних предметів, вимагають креативності й критичного мислення, орієнтовані на розвиток особистості й набуття літературної компетентності. Виходячи 3 вище зазначеного, уважаємо пропоновану методику ефективною для використання на уроках української літератури в закладах загальної середньої освіти.

Висновки. Унаслідок проведення експериментального дослідження вдалося дійти таких висновків:
1. Використання розробленої й теоретично обгрунтованої моделі та різнорівневих завдань із літератури, які мали на меті залучення учнів до проєктної діяльності 3 подальшим формуванням ЛК за посередництва IКТ, сприяло тому, що старшокласники навчилися працювати в умовах пошуку, дослідження, створювати власний інформаційно-літературний продукт, усвідомлювати естетичний уплив унаслідок опрацювання художніх творів.

2. На основі отриманих результатів проведеного експерименту засвідчуємо, що розроблена методика є ефективною. Використання засобів IКТ та ресурсів Інтернету у творчій, проєктній, проблемно-пошуковій діяльності створило перспективи для інноваційної діяльності, усвідомлення загальних засад ідейно-художнього аналізу твору, вивчення життєвого й творчого шляху письменників, досягнення акмерозвитку учнями-читачами.

Перспективи подальших досліджень проблеми полягають у розробленні завдань iз літератури 3 формування медіаграмотності, аналітико-синтетичних умінь школярів за посередництва IКТ.

\section{ЛІТЕРАТУРА}

1. Бібік Н. М. Компетентність у навчанні. Енциклопедія освіти / Н. М. Бібік / Акад. пед. наук України; гол. ред. В. Г. Кремень. - Київ : Юрінком Інтер, 2008. - 1040 с.

2. Лернер І. Я. Дидактичні основи формування пізнавальної самостійності учнів при вивченні гуманітарних дисциплін: автореф. дис. на здобуття наук. ступеня д-ра пед. наук. 13.00.04 «Теорія і методика професійної освіти» / I. Я Лернер ; Москва, 1971. $20 \mathrm{c}$.

3. Небеленчук I. О. Діалогові технології навчання зарубіжної літератури учнів 5-7 класів : автореф. дис. канд. пед. наук : 13.00.02 «Теорія та методика навчання (зарубіжна література)» / Небеленчук Ірина Олександрівна ; Національний педагогічний університет імені М. П. Драгоманова. - Київ, 2011. - 29 с.

4. Пєхота О. М. Освітні технології : навч.-метод. посіб. / О. М. Пєхота, А. З. Кіктенко, О. М. Любарська та ін.; за заг. ред. О. М. Пєхоти. - Київ : А.С.К., 2001. - 256 с.

5. Про освіту : Закон України від 21.09.2017. - № 38-39, ст. 380 // Відомості Верховної Ради. [Електронний ресурс]. - Режим доступу: https://zakon.rada.gov.ua/laws/show/ 2145-19.

6. Селевко Г. К. Энциклопедия образовательных технологий / Г. К. Селевко. В 2-х т. Т. 1, Москва : Народное образование, 2005.

7. Ситченко А. Л. Навчально-технологічна концепція літературного аналізу : моно- 
графія / А. Л. Ситченко. - Київ : Ленвіт, 2004. - 138-139 с.

8. Токмань Г. Л. Вікова психологія як наукове джерело методики викладання літератури / Токмань Ганна Леонідівна // Дивослово, 2003. - № 6. - С. 26-29.

9. Ушинський К. Д. Людина як предмет виховання. Спроба педагогічної антропології: вибр. Твори / К. Д. Ушинський. - Київ : Рад. шк., 1983. - Т. 1. - 480 с.

10. Фасоля А. М. Літературна освіта : компетенції, компетентності, знання, уміння і навички / А. М. Фасоля // Українська література в загальноосвітній школі : науково-метод. журнал. - 2012. - № 6-7. - С. 26-32.

11. Хуторской А. В. Современная дидактика: учебник для вузов / А. В. Хуторской. - СПб: Питер, 2001. - 544 с.

12. Шкловська О. Н. Формування читацької компетенції старшокласників у процесі вивчення зарубіжної літератури : автореф. дис. канд. пед. наук : 13.00 .02 «Теорія й методика навчання» (зарубіжна література) / Олена Наумівна Шкловська; [Запорізький національний університет]. - Київ, 2007. - С. 9.

13. Шуляр В. І. Сучасний урок літератури / В. І. Шуляр. - Харків : Основа, 2009. $121 \mathrm{c}$.

14. Шуляр В. I. Теоретико-методологічні засади сучасного уроку української літератури в основній і старшій школі: автореф. дис. на здобуття наук. ступеня д-ра. пед. наук : 13.00.02 «Теорія й методика навчання» (українська література) / Василь Іванович Шуляр ; Херсон, 2015. - 44 с.

15. Якиманская И. С. Личностно-ориентированное обучение в современной школе / И. С. Якиманская. - Москва : Сентябрь, 1996. - 95 с.

16. Яценко Т. А. Развитие литературной компетентности учеников в процессе изучения художественной национальной литературы в общеобразовательных школах Украины / Яценко Т. А. : материалы Международной заочной научно-практической конф., 27.11.2012 г. Часть I. / Яценко Тамила ; Новосибирск : СибАК, 2012. - С. 36-45.

17. Яценко Т. А. Формування компетентнісного читача на уроках літератури в основній школі / Таміла Олексіївна Яценко // Українська література в загальноосвітній школі : науково-метод. журнал. - 2012. - № 5. - С. 8-10.

18. Braun E., Leidner B. Academic course evaluation theoretical and empirical distinctions between selfRated gain in competences and satisfaction with teaching behavior / Braun E., Leidner B. // Eur. Psychol, 2009. - № 14. - P. 297-306.

19. Braun E. Selfrated competences questionnaires from a design perspective / Braun E. et al. ; Educ. Res. Rev, 2012. - № 7. - P. 1-18. DOI: 10.1016 / j.edurev.2011.11.005.

20. Estriegana Rosa Valdehita, Medina-Merodio José-Amelio and Barchino Plata Roberto. Student acceptance of virtual laboratory and practical work: An extension of the technology acceptance model, Computers \& Education, 10.1016/j.compedu.2019.02.010, 2019. [Electronic resource]. - Access mode: https://onlinelibrary. wiley.com/doi/10.1002/cae.22056.

21. Freeman C., Soete L. Developing science, technology and innovation indicators : What we can learn from the past / Freeman C., Soete L. // Research Policy, 2009. - Vol. 38. № 4. - P. 583-589.

22. Kwok Wing Lai, Kian Sam. Hong Technology use and learning haracteristics of students in higher education: Do generational differences exist? / Kwok Wing Lai, Kian Sam // University of Otago College of Education, New Zealand, 2015. - [Electronic resource]. Access mode: https://onlinelibrary.wiley.com/ doi/pdf/10.1111/bjet.12161.

23. Sultan Sultan, Rofiuddin Ahmad, Nurhadi, Priyatni Endah Tri. Development of Mass Media Text-Based Instructional Materials to Improve Critical Reading Skills of University 
Students. Pedagogy, 2018. - Vol. 131. - № 3. - pp. 26-47. DOI:10.15823/p.2018.32.

24. Vaskivska H., Palamar S., Nazarenko L. Didactic factors of formation of literary competence of senior pupils in the process of implementation of information and communication technologies / Vaskivska H., Palamar S., Nazarenko L. // Балканско научно обозрение, 2017. - № 1. - C. 30-36.

\title{
ЭФФЕКТИВНОСТЬ ФОРМИРОВАНИЯ ЛИТЕРАТУРНОЙ КОМПЕТЕНТНОСТИ СТАРШЕКЛАССНИКОВ СРЕДСТВАМИ ИКТ (СТАРШАЯ ШКОЛА)
}

\author{
Назаренко Людмила, \\ кандидат педагогических наук, \\ дочент кафедры теории и методики \\ языково-литературного и \\ художественно-эстетического образования \\ Николаевский областной институт \\ последипломного педагогического образования \\ ул. Адмиральская, 4-а, 54001, г. Николаев, Украина \\ liudmyla.nazarenko@moippo.mk.ua
}

В статье затронута проблема формирования аксиологической компетентности учашихся средствали литературы, предпринята попытка определить противоречия, которые существуют в обществе по данной проблеме. Актуализирована потребность ежедневного труда в признании общечеловеческих ценностей. Проанализирована и конкретизирована суть понятия «аксиологическая компетентность», предложен собственный взгляд на дефинищию. Представлены взгляды ученых на понятия «мораль» и «духовность». Определень подходы, принципь формирования аксиологической компетентности учащихся.

Акиентировано внимание на первоочередной задаче учителя в условиях духовного роста его воспитанников - становление морально здоровой, всесторонне одаренной личности.

Отмечается важность использования эффективных заданий на уроках украинской литературы с изелью удовлетворения духовных запросов школьников, влияния на их моральный рост. Предусмотрены и охарактеризованы условия, благодаря которым обучение будет успешным. На основе программы по украинской литературе (уровень стандарта) учашимся 10-11 классов предложены аксиологическая составляющая изучаемых тем, задания для достижения заранее запланированного позитивного результата.

Очерчена специфика украинской литературы как искусства слова, влияния на читателя. Утверждается, что создание соответствующей образовательной среды, применение аксиологического, деятельностного, личностно ориентированного, компетентностного подходов, учёт принципов гуманности, связи с жизнью, сознательности и активности, использование иелостной системь методов, форм, средств и заданий будет способствовать успешному формированию аксиологической компетентности учашихся.

Ключевые слова: анализ художественного произведения; информационно-коммуникационные технологии (ИКТ); литературная компетентность (ЛК); осознанное восприятие; практические задачи; проектная деятельность, эксперимент. 


\title{
EFFICIENCY OF LITERARY COMPETENCE DEVELOPMENT OF HIGH SCHOOL STUDENTS BY ICT MEANS
}

\author{
Nazarenko Lyudmila, \\ candidate of pedagogical Sciences, \\ associate Professor of the Department of theory and methodology \\ of language-literary and artistic-aesthetic education \\ Mykolaiv In-Service Teachers Training Institute \\ 4-a Admiralska Street, 54001, Mykolaiv, Ukraine \\ liudmyla.nazarenko@moippo.mk.ua
}

The article actualizes the need for qualitative changes in education, changes in teaching Literature within the new strategy for training graduates of general education schools. The contradictions between teachers' use of traditional methods of teaching and the need for innovation; retransmission of knowledge and independent acquisition of information on the subject, its transformation and representation; the occasional use of Project training, a synergistic approach and a competence-activity paradigm for participants in the educational process are clarified. The content and essence of the concept «literary competence» (LC) of student-readers is deepened. Functions, criteria, and key components of high school students' Literature Competence development are proposed. A methodological model for the development of students' literary competence using ICT tools is designed.

The results of experimental training of high school students in quantitative and qualitative aspects regarding the acquisition of LC by students are revealed, and the influence of the use of ICT tools on literary competence development is justified. The results of an experimental study are summarized, they prove the effectiveness of the developed model for the LC of high school students by means of ICT, and the importance of applying project-based training.

Keywords: analysis of art pieces; conscious perception; information and communication technologies (ICT); experiment; literary competence (LC); practical tasks; project activity.

\section{REFERENCES}

1. Bibik, N. M. \& Kremen, V. H. (Ed.). (2008). Kompetentnist u navchanni. Entsyklopediia osvity [Competence in learning. Encyclopedia of Education]. Kyiv: Yurinkom Inter (ukr).

2. Fasolia, A. M. (2012). Literaturna osvita : kompetentsii, kompetentnosti, znannia, uminnia i navychky [Literary education: competencies, competencies, knowledge, skills and abilities]. Ukrainska literatura v zahalnoosvitnii shkoli, 6-7, 26-32 (ukr).

3. Hutorskoj, A. V. (2001). Sovremennaja didaktika [Modern didactics]. SPb: Piter (rus).

4. Jacenko, T. A. (2012). Razvitie literaturnoj kompetentnosti uchenikov v processe izuchenija hudozhestvennoj nacional'noj literatury v obshheobrazovatel'nyh shkolah Ukrainy [Development of literary competence of students in the process of studying national fiction literature in general education schools of Ukraine]: materialy Mezhdunarodnoj zaochnoj nauchno-prakticheskoj konf., 27.11.2012 g. Chast' I. Novosibirsk: SibAK, 36-45 (rus).

5. Jakimanskaja, I. S. (1996). Lichnostno-orientirovanoe obuchenie v sovremennoj shkole [Personal-oriented learning in a modern school]. Moskva: Sentjabr' (rus).

6. Law Of Ukraine vid 21.09.2017, 38-39, st. 380. Vidomosti Verkhovnoi Rady. Retrieved from: https://zakon.rada.gov.ua/laws/show/ 2145-19 (ukr).

7. Lerner, I. Ya. (1971). Dydaktychni osnovy formuvannia piznavalnoi samostiinosti 
uchniv pry vyvchenni humanitarnykh dystsyplin [Didactic foundations of the formation of cognitive independence of students in the study of Humanities]. (Extended abstract of doctor's thesis). Moskva (ukr).

8. Nebelenchuk, I. O. (2011). Dialohovi tekhnolohii navchannia zarubizhnoi literatury uchniv 5-7 klasiv [Dialogue technologies of teaching foreign literature to students of 5-7 grades]. (Extended abstract of candidate's thesis). Natsionalnyi pedahohichnyi universytet imeni M. P. Drahomanova. Kyiv (ukr).

9. Piekhota, O. M., Kiktenko, A. Z., Liubarska, O. M. \& et al. (2001). Osvitni tekhnolohii [Educational technologies]. Kyiv: A.S.K. (ukr).

10. Selevko, G. K. (2005). Jenciklopedija obrazovatel'nyh tehnologij [Encyclopedia of educational technologies]. V 2-h t. T. 1. Moskva: Narodnoe obrazovanie (rus).

11. Shklovska, O. N. (2007). Formuvannia chytatskoi kompetentsii starshoklasnykiv u protsesi vyvchennia zarubizhnoi literatury [Formation of reading competence of high school students in the process of studying foreign literature]. (Extended abstract of candidate's thesis). [Zaporizkyi natsionalnyi universytet]. Kyiv (ukr).

12. Shuliar, V. I. (2009). Suchasnyi urok literatury [Modern lesson of literature]. Kharkiv: Osnova (ukr).

13. Shuliar, V. I. (2015). Teoretyko-metodolohichni zasady suchasnoho uroku ukrainskoi literatury $v$ osnovnii $i$ starshii shkoli [Theoretical and methodological principles of the modern lesson of Ukrainian literature in primary and secondary school]. (Extended abstract of candidate's thesis). Kherson (ukr).

14. Sytchenko, A. L. (2004). Navchalno-tekhnolohichna kontseptsiia literaturnoho analizu [Educational and technological concept of literary analysis]. Kyiv: Lenvit (ukr).

15. Tokman, H. L. (2003). Vikova psykholohiia yak naukove dzherelo metodyky vykladannia literatury [Age psychology as a scientific source of methods of teaching literature]. Dyvoslovo, 6, 26-29 (ukr).

16. Ushynskyi, K. D. (1983). Liudyna yak predmet vykhovannia. Sproba pedahohichnoi antropolohii [A person as a subject of Education. An attempt at pedagogical anthropology]. Vybr. Tvory. T. 1. Kyiv: Rad. Shk. (ukr).

17. Yatsenko, T. A. (2012). Formuvannia kompetentnisnoho chytacha na urokakh literatury v osnovnii shkoli [Formation of a competent reader in Literature lessons of primary school]. Ukrainska literatura $v$ zahalnoosvitnii shkoli, 5, 8-10 (ukr).

18. Braun, E., Leidner, B. Academic course evaluation theoretical and empirical distinctions between self Rated gain in competences and satisfaction with teaching behavior / Braun E., Leidner B. // Eur. Psychol, 2009. - № 14. - P. 297-306 (eng).

19. Braun, E. Selfrated competences questionnaires from a design perspective / Braun E. et al. ; Educ. Res. Rev, 2012. - № 7. - P. 1-18. DOI: 10.1016 / j.edurev.2011.11.005 (eng).

20. Estriegana, Rosa Valdehita, Medina-Merodio, José-Amelio and Barchino Plata Roberto. Student acceptance of virtual laboratory and practical work: An extension of the technology acceptance model, Computers \& Education, 10.1016/j.compedu.2019.02.010, 2019. [Electronic resource]. - Access mode: https://onlinelibrary. wiley.com/doi/10.1002/cae.22056 (eng).

21. Freeman, C., Soete, L. Developing science, technology and innovation indicators : What we can learn from the past / Freeman C., Soete L. // Research Policy, 2009. - Vol. 38. № 4. - P. 583-589 (eng).

22. Kwok, Wing Lai, Kian, Sam. Hong Technology use and learning haracteristics of students in higher education: Do generational differences exist? / Kwok Wing Lai, Kian Sam 
// University of Otago College of Education, New Zealand, 2015. - [Electronic resource]. Access mode: https://onlinelibrary.wiley.com/ doi/pdf/10.1111/bjet.12161(eng).

23. Sultan, Sultan, Rofiuddin, Ahmad, Nurhadi, Priyatni, Endah Tri. Development of Mass Media Text-Based Instructional Materials to Improve Critical Reading Skills of University Students. Pedagogy, 2018. - Vol. 131. - № 3. - pp. 26-47. DOI:10.15823/p.2018.32. (eng).

24. Vaskivska, H., Palamar, S., Nazarenko, L. Didactic factors of formation of literary competence of senior pupils in the process of implementation of information and communication technologies / Vaskivska H., Palamar S., Nazarenko L. // Балканско научно обозрение, 2017. - № 1. - C. 30-36 (ukr). 